\title{
Girodet's Galvanized Bodies
}

Stephanie O'Rourke (University of St Andrews)

Accepted for publication in Art History; final version pending

'The body politic, like the body of man, begins to die as soon as it is born, and bears within it the seeds of its own dissolution.' Rousseau, Confessions ${ }^{1}$

'Oh sad nineteenth century! / GIRODET'2

When the French painter Anne-Louis Girodet exhibited his last major Salon painting, Pygmalion and Galatea (plate 1), in 1819, a bemused review in the Journal des dames et des modes noted that the figure of Eros, who unites the eponymous protagonists, 'seems to conduct (all jokes aside) a galvanic experiment. ${ }^{3}$ The review referred to a bright concentration of light that passes between the knees of Eros and the inanimate statue of Galatea, who is shown coming to life in front of the man who sculpted her. This galvanic - or, as we would call it, electric - experiment would have had several connotations for the Journal's readers. Named after the Italian scientist Luigi Galvani, whose experiments with frog legs were widely known throughout Europe (plate 2), a 'galvanic' experiment described the transmission of electricity through human and animal bodies. ${ }^{4}$ More colloquially, galvanism suggested to a French audience both visual and structural transformations: an intense luminous discharge accompanied by the animation of something inanimate. Its inclusion in Girodet's Pygmalion and Galatea served as a timely analogy for the process of bringing a statue to life. 
But although electricity was familiar to visitors of the 1819 Salon, its status in the social imaginary of post-Revolutionary France was far from straightforward. Electricity had initially become a subject of focused scientific enquiry under the monarchical ruling order of early eighteenth-century France. ${ }^{5}$ It had also been quickly incorporated into a variety of popular recreational activities, from polite demonstrations in fashionable drawing rooms to spectacular theatrical attractions on Paris's boulevards. In the decades immediately preceding Girodet's painting, though, electricity had acquired a decidedly republican valence associated with a model of radical political collectivity that reached its fullest expression in The Terror. Yet electricity was not simply, or not only, a Revolutionary metaphor. ${ }^{6}$ Electricity gave physical form to a psychic and corporeal experience in which the human body was activated as a particular kind of political subject. ${ }^{7}$ It articulated a provisional alignment of bodies and politics predicated on the lateral transmission of a powerful, immaterial force. This alignment - its possibilities as well as its failures - are, I will argue, precisely what Girodet explored in several of his large-scale history paintings.

Rather than focus on the personal or psychosexual politics of Girodet's work, I am interested here in situating his paintings within a densely tangled set of scientific discourses, popular spectacles, and political formations. And although this article revisits his pictorial treatment of the human body, it does so in relation to the visual and structural features of eighteenth-century electric experiments. ${ }^{8}$ The aim of this analysis is not so much to offer a different iconographical reading of Girodet's paintings. Instead, I argue that recourse to four of his major works - and especially to his Deluge of 1806 - furnish new and essential insights into what it may have meant, in political and representational terms, to figure a 'galvanized body' in the years during and after the French Revolution. 
Girodet's reputation among the foremost young stars of the French school had been secured by the exhibition of his Sleep of Endymion (plate 3) in the Salon of 1793, which was praised for its technical precision and inventive treatment of light. Sleep of Endymion depicts a rural shepherd of extraordinary beauty, portrayed as an académie-style nude submerged in unending slumber. The figure of Eros pulls back a dark curtain of foliage to allow Selene, goddess of the Moon, to enter the shaded grove in which he lies. The amorous contact of Endymion and Selene is figured as a vaporous encounter between moonlight and flesh, endowing this nocturnal illumination with a sense of intimate physicality. The porous boundary of Endymion's flesh, which dissolves under his lover's touch, also set the work at odds with the crisply delineated forms and more uniformly distributed light that characterized the work of Girodet's teacher, Jacques-Louis David. ${ }^{9}$ A certain interrelationship is thereby evoked between wakefulness and sleep, life and death, that accorded with vitalist theories of the time. ${ }^{10}$ The irony of Endymion's eternal sleep lay in the fact that it offered a form of immortality that is contingent upon the death-like inactivity of slumber. In some versions of the myth, it is Selene who is responsible for Endymion's somnolent state, which would further imply a curious opposition between the conditions of visibility and consciousness: Endymion is being illuminated by the very figure that has rendered him insensate. ${ }^{11}$ In this context, moonlight in the painting doubles as an immaterial agent that deactivates the conscious self when it breaches the surface of the body, as well as being the condition of possibility for that body's visibility.

By the time he exhibited Ossian (plate 4) in 1802, Girodet was a prominent, mature figure in the French School and enjoyed limited patronage from Napoleon and his wife 
Joséphine, who had commissioned Ossian to adorn the grand salon of the newly renovated château of Malmaison. ${ }^{12}$ Girodet, drawing upon the Scottish cycle of epic poems by James McPherson, imagined the fictional Nordic bard Ossian welcoming recently deceased French Napoleonic generals to an aerial Elysium. Allegorical figures soar above the central grouping, illuminated by orbs of varying coluor and intensity. Girodet here extended the porous corporeality of Endymion to an entire crowd. The diffuse lighting and compressed space soften and blur the boundaries between individual figures, in some places rendering them completely indistinguishable, almost a single translucent crush of spectral bodies.

Ossian's vaporous forms, obscure luminous effects, and spectral protagonists had perplexed critics, one of whom claimed that Girodet had 'drowned' the linear contours of his figures 'to give them a phantasmagoric appearance. ${ }^{\text {13 }}$ This reference to the Phantasmagoria, which evinced both formal and narrative resemblances, proved to be more precise than the critic for Le Publiciste may have even known - for, although Girodet maintained official lodgings in the Louvre, he also rented a studio in the same architectural complex that hosted Etienne-Gaspard Robertson's oft-cited Fantasmagorie from 1799 to $1805 .{ }^{14}$ The literal proximity of these two spaces - Girodet's atelier and Robertson's Phantasmagoria - could, at first glance, be reasonably taken for a coincidence. After all, the former Capuchin Convent that housed them both comprised a sizeable lot in central Paris just north of the Place Vendôme, and Girodet's was not the only studio in the area. Yet Ossian exemplified the readiness with which phosphorescent and electric effects slipped into the register of fairground showmanship and theatrical illusion. Even Girodet's choice of subject matter - the reappearance of the dead as luminous shadows against a dark backdrop - resonated with Robertson's Phantasmagoria, in which images of the dead were projected onto a screen in a 
darkened chamber. David himself recognized the painting's more figurative proximity to popular forms of entertainment, writing that Girodet dragged the beau idéal into 'the absurdity one applies to Melodramas. ${ }^{15}$ In the context of the Revolution, Peter Brooks has argued that melodrama was a specific and new theatrical mode which aimed to thrill its audience rather than to narrate or instruct. ${ }^{16}$ David's reference thus implies that Girodet's work is not only contiguous with a debased theatrical genre but that it has similarly abandoned the more substantial operations of history painting. ${ }^{17}$

Ossian is set in a densely populated celestial realm 'lit by meteors' and stars, whose radiant phosphorescence pervades the canvas. ${ }^{18}$ Girodet insisted that the viewer would find none of the commonplace tonalities associated with sunlight, moonlight, or terrestrial fire. ${ }^{19}$ In the artist's text 'The Critique of the Critiques of the Salon of 1806' of 1807, he mocked the much-discussed confusion surrounding Ossian's unusual illumination, writing: 'The air is $a$ large mirror: each object alternately reflects its colour and its day (i.e., light) to neighboring bodies. ${ }^{20}$ Girodet's riposte alludes to the fact that light and colour within the painting are not exclusively determined by intrinsic material properties nor by external light sources. Instead, the bodies seem to be reflecting off of one another and entering into a kind of visual sympathy with their neighboring objects. Physical adjacency becomes visual resemblance, constituting a formal collective in which luminous effects are amplified and transmitted locally, laterally, and non-hierarchically. Writing to his friend Bernardin de Saint-Pierre in 1805, Girodet had earlier reflected that the figures in Ossian 'had to appear porous, penetrable. ${ }^{21}$ It was an effect the artist claimed as 'a new conquest for painting,' although critics were more inclined to associate it with decidedly less highbrow forms of display. In Ossian, Girodet painted a crowd that is constituted by the dissolution of the individual body, 
a body even more radically porous than that of Endymion. Yet it was a body that was also deemed 'phantasmagoric.' Girodet's figures, with their 'diaphanous skin,' receive and transmit the luminous effects of neighboring bodies, subordinating the contours of the physical, bounded self to the aggregate body of an illusory crowd. ${ }^{22}$

A year after exhibiting Ossian, Girodet set to work on a new painting in his studio in the former Capuchin Convent. ${ }^{23}$ The resulting A Deluge, or Une Scène de déluge (plate 5), was first exhibited at the Salon of 1806, where it invited widespread critical acclaim. Indeed, although contemporary art historical scholarship has tended to direct its attention to Sleep of Endymion, it was Deluge that was widely regarded as Girodet's greatest work during his lifetime. The painting depicts a family, arrayed along a single axis, fleeing the rising waters of a catastrophic flood. The family's patriarch is supported by his young son, whose wife and small children struggle to maintain their grip on the ledge below. The central pairing of father and son was reminiscent of an oft-depicted episode from Virgil's Aeneid in which the young Aeneas carries his father on his shoulders as they flee Troy. The work also inspired frequent comparison to Nicolas Poussin's Le Déluge from the 1660s, but Girodet denied any relationship between them, insisting that his painting did not represent the Biblical Flood but merely 'a sudden and partial inundation produced by a convulsion of nature.' ${ }^{24}$

The primary fault for which Girodet's work was criticized resided less in the painting itself than in the overpowering effects it was said to have on its viewers. A similar charge had already been leveled at Ossian, which La Décade philosophique derided as 'a veritable physic for the eyes,' evoking the archaic sense of 'physik' (or in Old French, phisike) as a medicinal remedy commonly associated with violent and involuntary physical purging. ${ }^{25}$ The 
striking emotional content of Deluge elicited a refrain of descriptors such as 'horrible,' 'terrible,' and 'shocking,' aligning the work with both melodrama and the sensational idiom of early romanticism, the latter defined less by a consistent set of visual strategies than by formal obscurities and excesses that evoked a world beyond the threshold of ordinary perception. ${ }^{26}$ In short, critics associated Girodet's paintings firstly with affective responses that exceeded normative or acceptable intensity and, secondly, with corporeal effects suggesting states of physical vulnerability. ${ }^{27}$ Some treated Deluge akin to a public health hazard, claiming that it wounded or strained their eyes. 'What does it do to the spectator?' an indignant reviewer asked. 'The principal figure, turning his eyes and grinding his teeth in a convulsive attitude, cannot be regarded without horror. ${ }^{28}$ One popular anecdote indicated that even the most hardened viewers were not immune to the sentiment of 'pure horror'29 described by critics: 'Two soldiers looked at his painting in profound silence. One of them, after a few minutes, broke the silence by energetically crying out, "Thunder of the Deluge! [...] Oh! That poor mother!" Then, turning to his comrade he said, "Come, let's go. This painting makes me feel ill.", 30 This account was appended to the artist's 'The Critique of the Critiques of the Salon of 1806.' The poem's annotations, which were probably penned by the editor Firmin Didot, add that Girodet had been displeased to learn that his painting had an effect on its viewers similar to the first performance of Aeschylus's Eumenides ${ }^{31}$ Didot referred to the well-known claim that the shocking appearance of Aeschylus's Furies in the ancient Athenian theater had caused children to faint and pregnant women to miscarry. ${ }^{32}$

The emotional extravagance of Girodet's narrative was heightened by the scene's strange illumination, a single flash of lightning that mimics the diagonal alignment of the bodies, cutting from the top right into the penumbra of the lower left. Deemed 'too trenchant 
and disagreeable ${ }^{33}$ by critics, it was said to produce a 'false day. ${ }^{34}$ Particularly visible in Girodet's preparatory oil-on-wood sketch (plate 6), the use of lightning speaks to the artist's long-standing and intense fascination with alternative forms of illumination. It was while working on Deluge, shortly after exhibiting Ossian, that Girodet is said to have adopted the form of nocturnal painting for which he would later be known. Unable to complete his work during daylight hours, he would continue to paint by candlelight until $2 \mathrm{am}$. His friend and pupil Antoine-Claude Pannetier eventually created 'a mobile lighting apparatus,' which Girodet continued to use until his death. ${ }^{35}$ Girodet's use of an alternative light source in his studio would thus appear to echo his frequent recourse to non-solar forms of illumination in his large-scale history paintings.

Girodet's use of an artificial lighting apparatus while painting Deluge would have been one of several kinds of luminous projection occurring in the former Capuchin Convent where the painter's studio was housed. In an abandoned crypt within the same complex, Robertson's Phantasmagoria was titillating audiences with spectral apparitions that appeared to advance towards and recede from the spectator in a darkened chamber. ${ }^{36}$ Before visitors to the Phantasmagoria reached the primary auditorium, they passed through a brightly lit salon de physique containing theatrical displays, optical illusions, and scientific demonstrations that included electric shocks and sparks. As Tom Gunning has noted, the incongruity of this salon-style display and the immersive illusions awaiting the viewer in the next room served to heighten the effects of the Phantasmagoria, which, unlike the tricks in the salon de physique, concealed the apparatus that produced the illusion from the spectator. ${ }^{37}$ Robertson had studied optics and electricity in his youth, reading the texts of Jean Antoine Nollet and 
conducting his own playful experiments. In his memoires, for example, he recounts devising tricks with his growing knowledge of physics, one of which included sending an electric shock through a group of dancers. ${ }^{38}$ Upon his arrival in Paris, Robertson enrolled in a public physics course given regularly by M. Brisson, a professor at the Collège de France. There, he may have found himself seated alongside Girodet, who also attended one of M. Brisson's courses in experimental physics. ${ }^{39}$

In the Paris of Girodet's youth, 'everywhere science calls out to you and says, look. 40 So wrote Louis-Sébastian Mercier in his introduction to Tableau de Paris, a copy of which could be found in the modest personal library of the adolescent painter. ${ }^{41}$ Although some basic scientific instruction - particularly in anatomy - would have been a routine part of an artist's education, Girodet was encouraged to cultivate a much more extensive knowledge of science by his mentor, doctor Benoit-François Trioson. Like Robertson, Girodet acquired Jean Antoine Nollet's texts on electricity and physics in his youth, and pursued both formal and informal scientific training. The experimental physics course given by M. Brisson was one of dozens held annually in Paris. They enjoyed tremendous popularity in the 1780 s, and were known for combining spectacular demonstrations with didactic explication. In addition to producing flashes, sparks, and shocks, popular demonstrations drew upon Luigi Galvani's study of animal electricity to reanimate dead or paralyzed animals (a trick that would later resonate with the visual reanimation of dead Revolutionaries in Robertson's Phantasmagoria). Because electric experiments were both titillating and instructive, they doubled, in the words of James Delbourgo, as 'a rational curiosity and wonderful experience. ${ }^{42}$

The study of electricity had been undertaken with particular intensity starting in the 1720 s and 1730 s, when experimenters began to artificially generate and transmit - or, to use 
the technical term, 'communicate' - electrical virtue through various materials. Stephen Gray and John Desaguliers were among those who initially demonstrated these effects in London, and drew the attention of experimenters across Europe. The French chemist Charles du Fay, who visited London on several occasions, succeeded in 1733 in electrifying his own body and delivering sparks and shocks to those who touched him. In 1734 Gray arranged a half-dozen men into a chain and successfully communicated electricity between them at the Royal Society of London, then located in Crane Court. Du Fay replicated this experiment and others in Paris with his pupil Nollet, and by the 1740s electric experiments and recreational demonstrations were undertaken across Europe. In the mid-eighteenth century, electric demonstrations were no longer confined - spatially or institutionally - to Europe's academic societies and other learned bodies. By the 1780s, the audience for electric demonstrations even included the lower classes of Paris and the French provinces. Public lectures and courses in experimental physics (in which electricity featured prominently) were attended by thousands annually in the capital. As a journalist in L'Année littéraire noted in 1780, 'Never has the public taste for experimental physics been more general nor more widespread than today. ${ }^{43}$

Because electric demonstrations often included glowing bodies, sudden flashes, and bright sparks, they were particularly suited to a climate in which the boundaries separating public demonstrations, earnest scientific study, and mere entertainment were far from fixed. One of the features these activities held in common was their routine reliance on the human body as the primary agent for transmitting electricity (plate 7). ${ }^{44}$ This practice drew upon a mainstream eighteenth-century model of the nervous system as networks of hollow vessels through which a very small and fast-moving fluid or 'spirit' was thought to transmit 
sensation. ${ }^{45}$ (This principle was also key to animal magnetism, or 'mesmerism,' a healing practice with which electricity was often associated until it was famously discredited in $1784 .^{46}$ ) The use of the human body as an electric conductor was best exemplified in what became known as the 'human chain,' a variation on the experiment first demonstrated at Crane Court and later recounted by Robertson in his memoires. Nollet famously transmitted an electric shock through 180 royal guards at Versailles in front of King Louis XV and his court. The men held hands and were also connected by pieces of metal; when joined in an electric circuit, each man felt a simultaneous shock. The experiment was reproduced with 200 Carthusian monks from a nearby monastery. Over 600 people later participated in a human chain at the Collège de Navarre, 'all of whom felt the shock throughout their body with a violence proportional to the distance of each organ from the point of contact. ${ }^{47}$ Eighteenthcentury treatises insisted that 'the number of people who compose this chain is irrelevant; one hundred people will feel it the same is if there were only three or four. ${ }^{48}$

The human chain illustrated several key elements of electricity and the popular and scientific discourses surrounding it. Firstly, the human body, porous and permeable, was an ideal conductor through which electricity could flow. As the provincial doctor (and, later, Revolutionary politician) Jean-Paul Marat explained in his treatise on the medical uses of electricity, 'because the human body is permeable, the bones, cartilage, flesh, nerves, tendons etc. transmit [electricity] freely. ${ }^{49}$ Indeed, its effects could be transmitted almost instantaneously between a theoretically limitless number of people who were linked by their hands. Because electricity traveled laterally between these bodies, it was also understood to be a radically non-hierarchical phenomenon, a characteristic similarly true of the popular diffusion of its study outside the confines of elite academic societies. Moreover, electricity 
was characterized by its elusiveness, its lack of intrinsic materiality. Electricity was primarily observed in the effects it produced in other bodies or in transmission between them. In the case of the human chain, these effects were experienced as a shock, spark, or snap characterized by unexpected and brief pain. The basic activities of the experimenter included using his body to draw a spark (tirer l'étincelle), receive a shock (reçevoir une commotion), form an electric circuit (une chaîne), and deliver a jolt (une secousse). More devoted electric demonstrators routinely reported dizziness, nosebleeds, fevers, convulsions, and paralysis after using their bodies for prolonged experiments. ${ }^{50}$ One of the most famous accidents was recorded by Pieter van Musschenbroek, who invented the Leyden jar, a device that could store and transmit electric charges. During one of his experiments, the Dutch scientist received a shock 'so violent that he was terrified, and protested that he would not [agree to] receive a second one even if they made him the King of France.' 51

Electricity, in its experimental and popular applications, was transmitted through a body defined by its porousness. But it simultaneously provided a way of conceptualizing certain kinds of transmission, communication, and power. For example, it became a literary metaphor for various immediate and fleeting effects: Percy B. Shelley and Samuel Coleridge were among many romantic writers to incorporate the language of electricity in their works, evoking, on the one hand, the ineffable, and, on the other, intense affective and corporeal experiences. ${ }^{52}$ Given both the widespread popularity of electric demonstrations and Girodet's unusually advanced knowledge of science, it is perhaps unsurprising that references to electricity can be found in what remains of his personal writings. He described artworks as 'electrifying,' 'sparkling,' and producing 'a jolt., ${ }^{53}$ He defined genius as 'the sparkling shock 
of though $[\mathrm{t}],{ }^{, 54}$ and argued that great artworks traverse history as if conductors in an electric chain: 'these sublime models, resembling electric conductors, circulate from generation to generation the sparks of genius among all civilized peoples. ${ }^{55}$ Most explicitly, however, Girodet wrote that electricity characterizes the means by which a painting affects its viewers in his long-form poem of 1808, Le Peintre:

The artist of hearts, thus, follows each passion,

And knows to trace in them the right expression:

As soon as he feels, he makes, and suddenly communicates

To the moved spectator an electric spark. ${ }^{56}$

Girodet drew upon the metaphoric resonances of electricity to articulate the immediacy and intensity with which a successful artist moves his viewer. His use of the technical terms of experimental physics (e.g., 'communicates') also explicitly locates the painting's spectator within an experiment in which he receives the bright, sharp bite of an electric shock.

Electricity had long been associated with radicalism, and not just in France. ${ }^{57}$ The English natural philosopher Joseph Priestley, known for his political radicalism, was one of many who pitted electricity against social and political hierarchies: 'The English hierarchy (if there be anything unsound in its constitution) has equal reason to tremble, even at $[\ldots]$ an electrical machine. ${ }^{58}$ More specifically for Girodet, references to electricity proliferated in both painted and printed depictions of the French Revolution. Seen in the background of David's sketch for his unfinished Tennis Court Oath of 1791, a flash of lightning marked the transformative nature of the events taking place. Lightning became an especially powerful symbol in the mid-1790s, coinciding with the most radical and violent period of the Revolution. It could be seen bursting from the sky alongside the Republican Constitution 
(Louis Jean Allais, Constitution républicaine, 1793) and emanating from a Gallic Rooster, refashioned as an emblem for the French Republic, to jolt and unseat members of the European oligarchy (plate 8). A key to the print describes the rooster 'penetrating' the scene with 'the sign of equality from a lightning bolt that de-coifs' several monarchs. In JacquesLouis Pérée's seminal engraving The Rights of Man, 1794-95 (plate 9), a tree bearing emblems of the Church and monarchy has been struck down, presumably with the ax wielded by the muscular nude who occupies the centre of the print. Yet it is lightning, cutting diagonally across the composition, that sets the French Crown aflame. Electricity complements and activates the manual activity (which is implicitly slow and labourious) by which the tree was felled. In contrast, the lightning is instantaneous, immensely powerful yet intangible, and cannot be attributed to an individual agent. Man may have laid the wood for revolution, the print suggests, but the righteous electricity of liberty lit the fire.

Even the instruments of electric demonstrations were incorporated into prints. The caricature The Mass Fall (plate 10) depicts a republican activist sending an 'electric shock of liberty' to the corrupt officials of the ancien régime. The 'shock' is produced by an eighteenth-century electrical machine in which a rotating disk creates a static charge - here, though, instead of a plate it is the 'Declaration of the Rights of Man,' the same document referenced in Perée's print, that creates the electric charge. The device is even topped by a Phrygian bonnet. Text within the print informs us that 'republican electricity,' is delivering a shock that is incapacitating despotic leaders and toppling the political hierarchies to which they belong. The coil that transmits the electricity is accompanied by the words 'liberty,' 'equality,' 'fraternity,' 'unity,' and 'indivisibility.' Of critical relevance here is the nearinstantaneous and radically non-hierarchical way in which electricity was thought to travel 
through bodies, thus serving as an apt metaphor for both the form and the aspirations of Revolutionary sentiment. Its role as a Revolutionary metaphor persisted well into the nineteenth century. In Über die allmähliche Verfertigung der Gedanken beim Reden, written between 1805 and 1806, Heinrich von Kleist likened the spread of republican enthusiasm to the transmission of electric charges between bodies. Thomas Carlyle's 1837 history of The French Revolution later claimed that, 'France is a monstrous Galvanic Mass [...]; electrifying one another, positive and negative; filling with electricity your Leyden-jars - Twenty-five million in number! As the jars get full, there will, from time to time, be, on slight hint, an explosion. ${ }^{59}$

The public display of experimental natural philosophy, and electricity in particular, in the 1780 s and 1790 s appealed to audiences as a force that transgressed the bounds of human control. ${ }^{60}$ But the human chain that had been performed decades earlier by Nollet for King Louis XV acquired a more specific resonance for Revolutionaries. The human chain, as both a popular eighteenth-century demonstration and a Revolutionary metaphor, described a quite literal corporeal experience in which an immaterial 'spirit' or virtue was rapidly transmitted within and between individuals. The resulting configuration was a collective that was physically linked and laterally organized, grounding a Revolutionary subject in a body that was capable of receiving and transmitting an invisible force. Unable to direct the electricity that flowed through him, the subject of the human chain was merely a conductor of something larger, a link in a chain with no limit to its size. Even the physical properties of the human chain - difficult to contain or control, producing effects that are uniformly distributed, and joining together large numbers of people - echoed the tripartite cry of liberté, égalité, fraternité. 
The human chain was a literary metaphor, a corporeal experience, and also a model of political collectivity. Its political valence hinged on the 'erasure of the self' posited by Georg Hegel in his account of the Reign of Terror. ${ }^{61}$ Having dismantled a social experience that was organized and subdivided, Hegel indicates that Revolution offered in its place, 'a single whole': the concept of absolute freedom, in which 'all social ranks or classes... are effaced and annulled; the individual consciousness that belonged to any such group and exercised its will and found its fulfillment there, has removed the barriers confining it; its purpose is the universal purpose, its language universal law, its work universal achievement. ${ }^{62}$ As the 'stubborn atomic singleness' of the individual is dismantled by such social transformations, so, too, are his corporeal boundaries, grounding a Revolutionary model of collectivism, described here by Hegel, in a subject defined by his corporeal and psychic porousness.

The larger collective produced by the human chain was made possible by a subject who was defined not by his personal self-direction or autonomy but by the suppression of these very properties. Creating a subject who is physically and experientially continuous with those around him necessitates transgressing the boundaries of the self and, in so doing, deactivating what we might call one's 'self-possession.' Perhaps this was what Girodet first began to explore in his Sleep of Endymion, in which the linear contours of the heroic male nude are softened and dissolved, an effect that coincides with the subject's psychic suspension and physical vulnerability. Selene does not merely touch Endymion's body—she both breaches and illuminates it. Endymion's body is thus defined by its receptivity to a luminous substance, an immaterial force capable of passing through objects. ${ }^{63}$ Girodet's Ossian goes further, depicting a body that is more radically porous and by extension a subject whose boundaries are merely tentative wisps. The multitudes that welcome France's military 
heroes are fused into a single vaporous entity. Their diaphanous skin laterally receives and transmits the luminous effects of neighboring bodies, subordinating the contours of the bounded self to the aggregate body of the crowd. ${ }^{64}$ By 1802 , however, such a collective was already receding into a horizon of expired possibilities, for Girodet insisted, in his description of Ossian, that 'all the beings that compose it are fantastical, with the exception of Victory and the symbolic birds, which the artist depicts as really existing. ${ }^{65}$ In a stunning reversal of the representational registers of history and allegory, the only 'real' figures are those who are purely allegorical: the female Victory, the Gallic Rooster, and the Imperial Eagle. It seems that part of what had become 'unreal,' for Girodet, was the kind of corporeal and political body that could participate in a human chain.

Girodet's Deluge, painted just a few years after Ossian, presents its own kind of human chain whose structure is echoed in the transmission of electricity taking place behind it. The drama of the painting hinges on the physical connectivity of the individual figures, whose linked hands received careful attention from Girodet (plate 11). It was a configuration that recalled the transmission (or 'communication') of electricity in popular demonstrations (e.g., plate 12). The flash of lightning, the luminous discharge on which the visibility of the scene depends, replicates the diagonal alignment of bodies in the foreground. The oil-onwood sketch more explicitly points to the manual transmission of electrical virtue, the linking of hands that made a human chain possible. As the bright and jagged crack of lightning rends the canvas, it meets the ill-fated protagonist's left hand, passing behind and through his torso. The lightning continues just under the point of contact between the young man and his incapacitated wife, growing fainter where their son strives but fails to reach their linked arms. 
The critic Pierre-Jean-Baptiste Chaussard asked of this scene, 'One still sees the members of the same family clasping to and leaning on one another: but how can all the rings of this chain be linked to [just] one of them? ${ }^{66}$ Chaussard thus identified the figural grouping as a chain, but one that is structurally compromised. Jean-Baptiste-Bon Boutard, a frequent champion of Girodet's work, similarly expressed concern about 'this chain of people,' in which a sudden instability is 'communicated [from the father] to the other figures,' producing 'a jolt' which pushes their son off the face of the rock. ${ }^{67}$ Struggling to escape the rising waters of the flood, this family can only survive if they are able to preserve their physical connectivity, described here by Boutard in the language of electric transmissions. According to Boutard, however, what has been 'communicated' along this chain only serves to further imperil its participants.

Girodet's painting, I am suggesting, depicts a human chain in crisis. This corporeal configuration has been intensely destabilized, set askew along a dramatic diagonal axis. Each link, each point of continuity between the figures is on the verge of breaking. On the lower left, the young boy desperately clings to his mother's hair, but his fingers are already sliding through her uncoiled locks. Only the foremost tip of one of his feet remains on the rock. His mother has fainted, her neck limp and her knees buckling under the weight of her two children. Unresponsive to her husband's touch, the mother's fingers have gone slack. Above, the young man straddles two outcroppings of rock, his elderly father perched atop him. The older man's withered and inactive legs are set in contrast to those of his son, which bulge under the strain. Whereas the older man's free left hand clutches a purse of money, his son's hand firmly grips the family's sole anchor and collective hope: a single tree branch, which has begun to splinter. This configuration invokes, among other things, a patrilineal 
arrangement, a literal line of fathers and sons, that is about to be broken. Rather than part of an empowered model of collectivity united by immediate and shared corporeal experience, Girodet's protagonists are gravely endangered by the precarity of this organization. Its imminent collapse is anticipated by a single drowned figure on the lower left. Physically and visually isolated from the group, she reveals the consequences of being disconnected from the human chain. The solitude particular to this fate was described a few years earlier by William Cowper in his 1799 poem 'The Castaway,' in which a drowning crew 'perish'd, each alone,' despite their physical proximity. (This line would become an important refrain in Virginia Woolf's 1927 novel To the Lighthouse, gesturing to an uniquely modern experience of unbridgeable psychological isolation.) The drowned figure's physical separateness indicates the reinstatement of a post-Revolutionary subject who is similarly discrete and bounded.

The highly articulated musculature and the billowing drapery that entangles both the young mother and elderly patriarch give evidence of Girodet's close study of Michelangelo while in Rome. Girodet's composition, however, presents a kind of foil to the Creation of Adam found on Michelangelo's Sistine ceiling. If the Renaissance artist imagined an approaching moment of contact that would result in the transmission of vital energy to inactivated matter, Girodet presents the failure of such a touch. To the extent that the painting does indeed depict a human chain, it seems to indicate that this arrangement has ceased to offer a functional model of collectivism: to belong to this chain is to be endangered and insensate. Whereas the Davidian neoclassical nude had once encoded republican virtue, Girodet reveals the consummate powerlessness of this figure. ${ }^{68}$ The would-be young hero is incapable of saving his family and can only passively witness his own failure. In the words of 
one reviewer, 'he is gripped with horror at seeing the destruction of his family, which all his efforts can not prevent; his mouth opens with convulsion. ${ }^{69}$ Rather than a hero, Girodet has painted a spectator.

The response attributed to Girodet's protagonist resonates with those narrated by the painting's critics. 'Terrifying,' wrote Le Flâneur au Salon. ${ }^{70}$ 'Horrifying,' suggested the Athenaeum. ${ }^{71}$ These were terms often associated with the sublime, which had complex political resonances of its own in post-Revolutionary France. Although Burke had ominously predicted the Revolution's collapse in 1790 , the sublime was subsequently associated with the rhetoric of the Terror. Invoked most notably by Robespierre, it captured the grandeur and affective intensity that accompanied the Terror's purgative coupling of destruction and regeneration. But instead of invoking the sublime, reviews describe a specific aesthetic experience that was enfeebling instead of edifying and corporeal rather than mental. 'This sensation,' the Mercure de France complained, 'which prevents reasoning, and which is common to all the spectators, proves that the artist has overreached the goal he should have been content to attain. ${ }^{, 72}$ Those who view it, noted the Journal de l'Empire, 'must feel their nerves furiously irritated in casting their eyes on a painting such as the Déluge by M.

Girodet. ${ }^{73}$ Constant among such texts was the implication that the viewer could not control his or her responsiveness, that 'one is involuntarily moved in front of the painting of Une scène de déluge. ${ }^{74}$ Indeed, asked another, "who can look at this painting without shaking? ${ }^{95}$ The Gazette de France advised the viewer to moderate his or her exposure to the work in order to better evaluate its aesthetic content: 'Terror penetrates every sense when looking at this pathetic composition... It is necessary to leave the painting for a minute, to protect oneself from the illusion. ${ }^{76}$ These texts connote a mode of spectatorship in which the viewer 
is overpowered in both affective and physical terms, a mode that is exemplified in Girodet's erstwhile hero.

Girodet's own political identity was characterized by successive reversals and displacements. The second son of an aristocratic family in Montargis, his youth had been marked by privilege. His parents, born into a class of successful functionaries in the provincial haute bourgeoisie, eagerly pursued royalist affiliations in the house of the Duc d'Orléans. Their aristocratic pedigree, although on the ascent, was still young and relatively fragile. The social and financial aspirations of Girodet's parents were threatened by the increasingly dissolute behavior of their elder son, Antoine-Etienne, who was disinherited in the 1780s. When both parents died a few years later, the title and responsibility of the family estate fell to the younger son for whom they had never been intended, and whose education did not equip him to successfully manage it. Fatherless, Girodet was legally adopted by his longtime guardian Trioson in 1809, and he changed his name to Girodet-Trioson. Sonless, he mentored his cousin Antoine-César Becquerel, today known for his influential discoveries in the fields of electricity and luminescence.

Despite his royalist upbringing and aristocratic pedigree, Girodet actively supported the Revolution at its outset. He accompanied David during the storming of the Bastille, commemorating the event with a drawing of its victims. En route to Rome, Girodet was attacked outside of Lyon for being a suspected royalist agent. Upon his arrival in Italy, however, it was his republican affiliations that invited public harassment. Although he spent most of the Revolution in Italy, he openly identified himself there as both a Mason and Jacobin. Arrested and beaten on several occasions, he persisted in his proud and vocal identification with the Revolution and abandoned his aristocratic titles. ${ }^{77}$ Girodet eventually 
fled Rome at knifepoint after defending the Palais Macini, home to the Académie de France, from anti-republican riots. His description of the attack was sent to the National Assembly, and was read aloud during the session of 20 February $1793 .{ }^{78}$ Perhaps disillusioned by the public violence and political factionalism of the Terror, he would later describe that period as 'a nightmare' led by figures of 'criminal glory. ${ }^{79}$ By the time Girodet returned from Italy in 1795, he was courting the favor of the rising Napoleon. He eventually reclaimed his aristocratic title and became a vocal advocate for the Bourbon Restoration, embracing the very structures he had spent his youth fighting to dismantle.

This account, although relevant to any discussion of Girodet's politics, also outlines some of the conflicting identities and affiliations that characterized his experience of the French Revolution. Neither fully radical nor fully aristocratic, Girodet's position was unfixed. Unlike David, who preceded him, or Antoine-Jean Gros, who followed him, Girodet was never able to fully integrate himself into the social and artistic machinery of either Revolutionary or Imperial patronage. One might even imagine that this failure, the result of a kind of historical, social, and stylistic 'in-betweenness,' would make the painter particularly sensitive to the plight of his doomed hero in the Deluge: subject to the vicissitudes of powerful forces beyond his control, he is burdened by the weight of those both older and younger - a burden, it is clear, that is impossible to shoulder. ${ }^{80}$

At the Salon of 1819 Girodet exhibited his last major painting, Pygmalion and Galatea (Pygmalion et Galatée). The work, which had been commissioned by the Italian patron Giovanni Battista Sommariva, returned to and inverted the themes of his first Salon painting, Sleep of Endymion. At the beginning of his career, Girodet pictured a protagonist 
who had been put to sleep. At its close, a figure awakens. In Girodet's painting, Pygmalion watches with surprised delight as his artistic creation, the statue of Galatea, comes to life. Her feet retain the pale yellowish sheen of stone while her upper body flushes with the rosy glow of life. As one viewer remarked, '[her] blood already circulates, [and] the head and torso breath with life, whereas the legs are still alabaster. ${ }^{91}$ In between them, a small figure of Eros reaches out to delicately touch the hands of the artist and his beloved artwork, and a bright flash passes between the knees of Eros and Galatea. Although surrounded by a thick cloud of luminous incense, the body of Galatea is clearly bounded by an outline of pinks, browns, and blues. Even at the very point where Eros's spark meets her knee, the contours of her flesh remain unbreached.

Describing the bright, concentrated illumination of the scene, Étienne-Jean Delécluze wrote that it was painted 'like the flash of bare electricity. ${ }^{82}$ Another compared it to a 'luminous, electric explosion. ${ }^{, 83}$ Eros's agency in particular was coded in electric terms: 'It's the contact of Eros who, like the fire of an electric spark, has given the statue a soul! 84 Galvani's experiments decades earlier on frog legs had proven that muscles and nerves could be stimulated into action by electricity. This effect was commonly featured in the electric shows of the 1780 s through the 'reanimation' of dead or paralyzed birds, as conducted by popular showmen. At the turn of the century, Galvani’s nephew Giovanni Aldini travelled throughout Europe demonstrating his uncle's methods and giving large public lectures that involved applying electric charges to the bodies of dead animals. In London Aldini famously electrified the corpse of a recently executed man, Thomas Forster, for an audience of professionals, who watched with astonishment as the expired limbs jerked into motion. ${ }^{85}$ Nowhere in Girodet's œuvre is the visual language of electric experiments more explicitly 
cited than in Pygmalion. The bright yellow light that passes between Eros and Galatea transmits life to a previously inanimate being, as if Galatea was Galvani's frog leg, Aldini's corpse, or an electric demonstrator's paralyzed bird. Insofar as Eros is an electrical showman and Galatea is his subject, the results are couched in a narrative of amorous and aesthetic pleasure and Galatea exhibits none of the involuntary physical responses produced by electric shocks and associated, by critics, with Girodet's earlier paintings.

Pygmalion watches her transformation in wonder, a spectator who does not participate in the electric or somatic exchanges taking place between Eros and Galatea. The pearlescent horizontal line that connects their knees in an electric spark is not extended to Pygmalion, who is suspended in the moment before his touch reaches Galatea's breast. As in Girodet's Déluge, literal touch coincides with an electric transmission. On the right, the fleshy contact between Eros and Galatea is decisive, with two of his fingers curling as they meet Galatea's delicately extended forefinger. Yet on the left, Eros's fingers hover just above Pygmalion's wrist. The interstice separating their hands is marked by the vermillion of Pygmalion's cape peeking through from behind (plate 13). Whereas the ill-fated hero of the Déluge was both an agent in and spectator of the unfolding events, Pygmalion has been exempted from participating in or sustaining an electric circuit, in spite of the close relationship Girodet proffers between love, animation, and electricity. (The phallic nature of Eros's wing, suggestively placed at Pygmalion's hips, implies that he might be similarly displaced from a sexual exchange.)

The body of Galatea, the subject of the electric charge, is visually bounded and recast as an aesthetic object - something to be looked at rather than identified with. Meanwhile, her lover-turned-spectator is physically proximate to, but ultimately excluded from, the electric 
transmission that animates her. Four lines of poetry attached to the painting's frame during the Salon invoke a similarly inactive viewer: 'Charming painter of Endymion/ Come enjoy the transports of an enchanted crowd;/ All of Paris for your Galatea,/ Has the eyes of Endymion. ${ }^{86}$ The lines, which may reference a version of the Endymion myth in which the shepherd sleeps with his eyes open, identify the reciprocity of Girodet's early and late paintings. Yet they also clearly associate spectatorship with a state of dramatic physical and mental passivity.

The protagonists seen in some of Girodet's earlier history paintings, including both Endymion and Ossian, had been defined on both formal and narrative levels by their porous corporeality. They were galvanized bodies, transmitting and receiving luminous effects, and in this way activated as potential Revolutionary subjects. The fleeting electric transmission that illuminated Deluge, revealed, in contrast, a corporeal configuration in crisis and a landscape in a state of catastrophe. With the collapse of the political collectivism called forth by the human chain, Girodet anticipated, in its place, a spectator who has been ejected from a participatory role of receiving and transmitting. Instead, he is consigned to the powerless passivity of 'being shocked. ${ }^{87}$ When it was exhibited, Girodet's Pygmalion and Galatea was a stylistic relic of an increasingly outmoded French school of painting. Yet it marked other kinds of expiration as well. To the extent that the conception of the body produced and described by electricity once had political purchase, it had become, in 1819 , a mere spectacle - a luminous display whose Endymion-like viewer is isolated, yielding, and static. Insofar as electricity shaped certain ideas about what it meant to witness an electric experiment and to participate in a political collective, this had become an act of passively receiving affective and corporeal provocations. Today, as the contours of collective experience are being 
redrawn by emergent social and informational networks, our present moment is compelled to once again interrogate what it means to be a participant, a spectator, and a witness. If, indeed, this electric transmission is still capable of describing a lateral corporeal alignment united by effects that are experienced simultaneously and produced, transmitted, or amplified by its subjects, it belongs to an unrealized future.

Stephanie O’Rourke

University of St Andrews

\footnotetext{
${ }^{1}$ Jean-Jacques Rousseau, Les Confessions, bk. III ch. XI, Geneva, 1782.

${ }^{2}$ This quote may be apocryphal; it was cited by Stendhal in The Red and the Black (first published in 1830) as an epigraph to Chapter XXIX (titled 'L'Ennui'): 'Se sacrifier à ses
} 
passions, passe: / Mais à des passions qu'on n'a pas! O triste dix-neuvième siècle!/

\section{GIRODET.'}

3 'L'Amour est au milieu, et il semble faire (sans plaisanterie) une expérience de galvanisme.' Evariste, 'Huit jours à Paris', Journal des dames et des modes, 62, 1819, 510.

${ }^{4}$ The most literate among the Journal's readers may have also been familiar with Mary Shelley's Frankenstein, which was published in England the previous year but did not appear in French translation until 1821.

${ }^{5}$ Jessica Riskin has put forward an excellent account of the relationship between the natural sciences (including electricity) and French moral and political thought of the eighteenth century. Riskin, Science in the Age of Sensibility: The Sentimental Empiricists of the French Enlightenment, Chicago, 2002.

${ }^{6}$ For its status as a political metaphor in the American context, see: James Delbourgo, A Most Amazing Scene of Wonders: Electricity and Enlightenment in Early America, Cambridge Mass., 2006.

${ }^{7}$ This article takes inspiration from de Baecque's discussion of politics and the body in the French Revolution. Antoine de Baecque, The Body Politic: Corporeal Metaphor in Revolutionary France, 1770-1800, trans. Charlotte Mandell, Stanford, 1997. Another important text on this topic is Dorinda Outram, The Body and the French Revolution: Sex, Class, and Political Culture, New Haven, 1989.

${ }^{8}$ Although the relationship between the body and politics is familiar terrain in historical accounts of Girodet's art, this essay is indebted to but also sets aside the psychosexual framework through which it has often been approached. Influential examples of this include Darcy Grigsby, Extremities: Painting Empire in Post-Revolutionary France, New Haven, 
2002; Satish Padiyar, Chains: David, Canova, and the Fall of the Public Hero in Postrevolutionary France, University Park Penn., 2007; and Abigail Solomon-Godeau, Male Trouble: A Crisis in Representation, London, 1997.

${ }^{9}$ For an account of the personal and political consequences of this, see Thomas Crow, Emulation: Making Artists for Revolutionary France, New Haven, 1995. Crow argues that David's atelier, as both a space of male sociability and a structure governing a network of personal and professional relationships, embodied both the utopian promises and failings of the Revolutionary years. In the absence of a stable and viable image of heroic action, Revolutionary hopes and anxieties were articulated in the artists' various forms of engagement with the male body.

${ }^{10}$ Kevin Chua, 'Girodet and the Eternal Sleep', Vital Matters: Eighteenth-century Views of Conception, Life, and Death, eds. Mary Terrall and Helen Deutsch, Toronto, 2012, 57-92

${ }^{11}$ Although Roman and Renaissance variants of the myth differed, in the Greek version of the tale Selene, goddess of the Moon, was in love with the shepherd and convinced Zeus to put him to sleep in order to preserve his beauty and youth. Another version counters that Endymion angered the god and was put to sleep as a punishment. The Dictionnaire de la fable of 1801, to which Girodet anonymously contributed several entries, summarizes both versions of the tale. F.-J.-M. Noël, Dictionnaire de la fable, Paris, 1801, 372-373.

${ }^{12}$ The full, and rather onerous, title reads: L'Apothéose des héros français morts pour la Patrie pendant la guerre de la Liberté, Les ombres des héros morts pour la Patrie conduites par la Victoire viennent habiter l'Élysée aérien où les ombres d'Ossian et de ses valeureux guerriers s'empressent de leur donner dans ce séjour d'immortalité et de gloire la fête de la Paix et de l'Amitié. 
13 '[L]es contours y sont noys pour leur donner comme une apparence phantasmagorique.' Anon., 'Salon de l'an 10. No. IV', Le Publiciste, 1802, 2. This contemporary review affirms what Sarah Burns has noted about the phantasmagoric appearance of Girodet's figures. Sarah Burns, 'Girodet-Trioson's Ossian: The Role of Theatrical Illusionism in a Pictorial Evocation of Otherworldly Beings', Gazette des Beaux-Arts, 95, 1980, 13-24.

${ }^{14}$ Girodet began renting an atelier in the Couvent des Capucines in 1800 . He showed the near-completed Ossian to visitors at the smaller studio in his Louvre apartment in 1802, suggesting that he may not have executed that painting at his rented atelier. However, archival documentation confirms that Une scène de déluge was begun and completed there. Sidonie Lemeux-Fraitot, appendix to 'Ut poeta pictor: les champs culturels et littéraires d'Anne-Louis Girodet-Trioson', PhD diss., Université de Paris I - Panthéon-Sorbonne, 2002, $36-37$.

15 'Fragment d'une autobiographie de Louis David, c. 1809', ENSBA, Ms 316 no 51, f. 3, v., quoted in 'Biochronologie', Girodet 1767-1824, ed. Sylvain Bellenger, Paris, 2005, 571. ${ }^{16}$ See Peter Brooks, 'Melodrama, Body, Revolution', Melodrama: Stage, Picture, Screen, eds. Jacky Bratton, Jim Cook and Christine Gledhill, London, 1994.

${ }^{17}$ Whitney Davis has written of Endymion's psychic and corporeal suspension as the rejection of a Davidian constellation of masculinity, politics, and public history in 'The Renunciation of Reaction in Girodet's Sleep of Endymion', in Visual Culture: Images and Interpretations, eds. Normal Bryson, Michael Ann Holly, and Keith Moxey, Hanover, 1994, $168-201$.

${ }^{18}$ A.L. 'Tableau de Girodet (Ossian)', Journal des Arts, 19 June 1802, 28.762 Collection Deloynes, Bibliothèque nationale de France. 
${ }^{19}$ Girodet to Saint-Pierre, 26/7 October 1805, 'Biochronologie', ed. Sylvain Bellenger, 515. For an excellent account of the aesthetic and scientific implications of this mode of illumination, see Barbara Stafford, 'Les 'Météores' de Girodet', Revue de l'art, 46, 1979, 4651.

${ }^{20}$ Anne-Louis Girodet-Trioson, La Critique des Critiques: du sallon [sic.] de 1806, Paris, $1807,19$.

${ }^{21}$ Girodet to Bernardin de Saint-Pierre, [December 1805], Coupin, vol. II, 277-281.

22 'Salon de 1'an 10', Le Publicist, 3.

${ }^{23}$ The earliest sketches for the painting were undertaken around 1795, shortly before his return from Italy, where he studied for five years on a Prix de Rome.

${ }^{24}$ The confusion stemmed, according to the artist, from an error in the title: it was not d'un Déluge but merely de Déluge. The mistakenly added pronoun (un) had led its initial viewers to assume that Girodet had painted a biblical Diluvian scene. A. L. Girodet, 'Aux rédacteurs du journal', Journal de Paris, 21 September 1806, 1936.

25 'Beaux-Arts. Suite de l'examen du Salon', La Décade philosophique, littéraire, et politique, 1802, 551.

${ }^{26}$ For examples, see: 'Salon de 1806 (iiè article)', Mercure de France, 26, 1806, 26-31. 'Nouvelles concernant les sciences, arts et belles-lettres (Salon de 1806)', Athenaeum ou Galerie français, 9, September 1806. 'Suite du Salon de 1806. Tableau de M. Girodet, représentant une scène d'un deluge', Athenaeum ou Galerie français, 12, December 1806. J.B. Saint-Victor, 'Vers faits en voyant le tableau d'une scène de déluge, par M. Girodet', Journal de L'Empire, 13 October 1806, 4. Le Glaneur, 'Glanage dans le Salon', Journal de Paris, 1806, 38.1043, Collection Deloynes, Bibliothèque nationale de France. 
${ }^{27}$ The 'physicality' of aesthetic responsiveness in this period has been discussed in detail with regard to the Gothic novel, a genre that rose to popularity in the final decades of the eighteenth century. See, for example, Terry Castle, 'The Gothic Novel,' in Boss Ladies, Watch Out! (New York: Routledge, 2002).

${ }^{28}$ [D.B.?], 'Secondes observations sur le Salon de 1806,' Journal du publicist (1806) 38.1050 Collection Deloynes, Bibliothèque nationale de France.

29 'Suite du Salon de 1806,' Athenaeum ou Galerie française, 4.

${ }^{30}$ Anne-Louis Girodet-Trioson de Roussy, 'Notes,' La Critique des Critiques: du sallon [sic.] de 1806 (Paris: Firmin Didot, 1807), 37.

${ }^{31}$ Trioson, La Critique des Critiques, 37.

${ }^{32}$ For a discussion of this performance and a summary of its context, see Pat Easterling, 'Theatrical Furies: Thoughts on Eumenides,' Performance, Iconography, Reception, eds. Martin Revermann and Peter Wilson (New York: Oxford University Press, 2008): 219-236. ${ }^{33}$ [D.B.?], 'Secondes observations,' 437.

${ }^{34}$ F.C., 'Lettre sur le salon de 1806,' Journal des archives littéraires, ou mélanges de literature, d'histoire et de philosophie (1806) 38.1047 Collection Deloynes, Bibliothèque nationale de France.

${ }^{35}$ Pierre-Alexandre Coupin, Euvres posthumes de Girodet-Trioson, peintre d'histoire vol. I (Paris: Jules Renouard, 1829), xliv.

${ }^{36}$ Robertson, as he is more commonly known, opened his Fantasmagorie in the former Capuchin Convent in January of 1799, where it remained until 1805. The complex was later cut through by Napoleon to enable the construction of Rue de la Paix. 
${ }^{37}$ For further discussion of the distinction between these two components of Robertson's display, see Tom Gunning's seminal essay 'Illusions Past and Future: The Phantasmagoria and Its Specters,' http:///www.MediaArtHistory.org, a text for the First International Conference on the Histories of Art, Science, and Technology, 2004. ${ }^{38}$ Étienne-Gaspard Robertson, Mémoires récréatifs, scientifiques et anecdotiques vol. I (Paris: Chez l'auteur Blvd. Montmartre no. 12, 1833), 9.

${ }^{39}$ These classes, dozens of which were offered annually in late eighteenth-century Paris, were generally conducted outside of conventional academic structures. Yet Geoffrey Sutton has argued that 'the demonstration-lecture, replete with explosions and splashes and sparks, became the primary locus for the exposition of the truth of science and by extension for the demonstration of Enlightenment.' Geoffrey V. Sutton, Science for a Polite Society: Gender, Culture, and the Demonstration of Enlightenment (Oxford: Westview Press, 1995), 8. For more on Girodet's education, including his physics class, see: Lemeux-Fraitot, 'Ut Poeta Pictor,' 58.

${ }^{40}$ Louis-Sébastien Mercier, Panorama of Paris: selections from Tableau de Paris, trans. Helen Simpson (University Park: Pennsylvania State University Press, 1999), 30.

${ }^{41}$ Sidonie Lemeux-Fraitot, Appendix, 'Ut Poeta Pictor: Les champs culturels et littéraires d'Anne-Louis Girodet-Trioson' (PhD diss., University de Paris I-Panthéon Sorbonne, 2003). ${ }^{42}$ Because electric experiments relied upon the human body, 'in no other branch of enlightened science were the act of cognition and the experience of passion more intensely related: to know was to feel, and to feel was to know.' Delbourgo, 8-9.

${ }^{43}$ As quoted in Heilbrun, 199. 
${ }^{44}$ Simon Schaffer, 'Experimenter's Techniques, Dyers' Hands, and the Electric Planetarium' Isis 88 no. 3 (1997), 456-83.

${ }^{45}$ This idea was echoed in the theories of eighteenth-century materialists, who posited a self that is contingent upon, made up of, or continuous with the materiality of the body. In am influential essay on David's 1794 self-portrait, T.J. Clark explores the consequences of these theories on self-knowledge and self-representation, observing that, 'we know what we mean by calling flesh penetrable.' T.J. Clark, 'Gross David with the Swoln Cheek: An Essay on Self-Portraiture,' Rediscovering History: Culture, Politics, and the Psyche, ed. Michael S. Roth (Stanford: Stanford University Press, 1994), 253. However, a much more extensive and recent consideration of this can be found in Kevin Chua, 'Girodet and the Eternal Sleep.'

${ }^{46}$ For more on this relationship see Darnton.

${ }^{47}$ M. Sigaud de la Fond, Précis historique et expérimental des phénomènes électriques (1785) as translated and reprinted in Marcello Pera, The Ambiguous Frog: The Galvani-Volta Controversy on Animal Electricity, trans. Jonathan Mandelbaum (Princeton, NJ: Princeton University Press, 1986), 13.

${ }^{48}$ M. Guyot, Nouvelles récréations physiques et mathématiques (Paris: Gueffier, 1786), 320.

${ }^{49}$ Marat, Mémoire sur l'électricité médicale, 189.

${ }^{50}$ This feature, widely noted, is nicely summarized in John L. Heilbron, Electricity in the $17^{\text {th }}$ and $18^{\text {th }}$ centuries: A Study of Early Modern Physics (Berkeley: University of California Press, 1979), 314.

${ }^{51}$ Guyot, 223.

${ }^{52}$ The relationship between electricity and literary romanticism has been recently explored by Paul Gilmore's Aesthetic Materialism: Electricity and American Romanticism (Stanford, CA: 
Stanford University Press, 2009).

${ }^{53}$ The contemporary terms, in French, were frappant, électrisant, étincelant, and une secousse.

${ }^{54}$ Anne-Louis Girodet, Considérations sur le génie particulier à la peinture et la poésie, in Coupin, Euvres posthumes, vol. II, 103-4.

${ }^{55}$ Girodet, Sur le génie, in Coupin, Euvres posthumes, vol II, 121.

56 'L'artiste, ainsi, des coeurs suit chaque passion,/Et sait en retrace la juste expression: /Dès qu'il sent, il produit, et soudain communique /Au spectateur ému l'étincelle électrique.' Coupin, vol. I, 1. Girodet worked on 'Le Peintre' for an extended period of time. I give 1808 as its date, following Coupin, on the basis that it was in 1808 that Girodet corresponded with Fermin-Didot about publishing it.

${ }^{57}$ For the English politics of late eighteenth-century electricity, see Iwan Rhys Morus, 'Radicals, Romantics and Electrical Showmen: Placing Galvanism at the End of the English Enlightenment' Notes and Records of The Royal Society 0 (2009), pp. 1-13 and Simon Schaffer, 'Priestley and the politics of spirit,' in Science, medicine and dissent: Joseph Priestley (1733-1804), ed. Robert Anderson and Christopher Lawrence (London: Wellcome Trust, 1987), pp 39-53.

${ }^{58}$ Joseph Priestley, Experiments and Observations on Different Kinds of Air (Birmingham: Thomas Pearson, 1790), p xxiii.

${ }^{59}$ Thomas Carlyle, The French Revolution, vol. 2 pt.3 ch. II (London: Chapman and Hall, 1837), 144.

${ }^{60}$ Simon Schaffer, 'Natural Philosophy and Public Spectacle in the Eighteenth Century,' History of Science 21 (1983), 1-43. 
${ }^{61}$ Gilmore, 65.

${ }^{62}$ George Wilhelm Friedrich Hegel, The Phenomenology of Spirit, trans. J.B. Baillie (New York: Harper \& Row, 1967), 585.

${ }^{63}$ This relationship was first briefly alluded to by Barbara Stafford, who notes that Endymion's body is 'both absorbing and radiating, stimulated and stimulating to produce "effects" informed by contemporaneous ideas about electricity, phosphorescence, light, and the states of matter. Barbara Stafford, 'Endymion's Moonbath: Art and Science in Girodet's Early Masterpiece,' Leonardo 15, no. 3 (1982), 194.

64 'Salon de 1'an 10,' Le Publicist, 3.

${ }^{65}$ Explication des ouvrages de peinture et dessin...exposé au Muséum central des arts...an X de la République française (Paris: Impr. des sciences et arts, 1802), 111.

66 'On voit toujours les membres d'une même famille se serrer et s'appuyer l'un sur l'autre: mais comment rattacher à un seul tous les anneaux de cette chaîne?' P.-J.-B. Chaussard, Le Pausanias français; état des arts du dessin en France, à l'ouverture du XIXe siècle : Salon de 1806 (Paris : F. Buisson, 1806), 123.

${ }^{67}$ Boutard, 'Salon de l'an 1806 (No. III), 2.

${ }^{68}$ Accounts of the decline of the neoclassical nude are numerous and varied. Key examples include T.J. Clark, 'Painting in the Year 2,' in Farewell to an Idea (New Haven, CT: Yale University Press, 1999). Tom Crow, 'A Child Shall Lead Them,' in Emulation: David, Drouais, and Girodet in the Art of Revolutionary France (New Haven, CT: Yale University Press, 2006). Padiyar, Chains. Alex Potts, 'Ideal Bodies' in Flesh and the Ideal: Winckelman and the Origins of Art History (New Haven, CT: Yale University Press, 1994). An excellent account of a highly relevant transformation in Great Britain can be found in Martin Myrone, 
Bodybuilding: Reforming Masculinities in British Art 1750-1810 (New Haven: Yale

University Press, 2005).

${ }^{69}$ F.C., 'Lettre sur le salon de 1806,' 443.

${ }^{70}$ Le flâneur au Salon ou Mr Bon-homme; Examen joyeux des tableaux mêlé de vaudeville (Paris: Aubry, 1806).

71 'Suite du Salon de 1806,' Athenaeum ou Galerie française, 3.

72 ‘Salon de 1806 (iiè Article),' Mercure de France, 28.

${ }^{73}$ N. 'La critique des critiques du Salon de 1806, etrenne aux connoisseurs,' Journal de l’Empire (11 February 1807), 3.

${ }^{74}$ Dandrée, 'Suite de la lettre sur la Peinture, insérée dans la feuille d'hier,' Journal de Paris (29 November 1810), 2286.

${ }^{75}$ [Aubry?], Lettres impartiales sur les expositions de l'an 1806 (Paris: Aubry et Petit, 1806), 27.

${ }^{76}$ A.D., 'Sallon [sic.] de 1806,' Gazette de France (17 September 1806), 1074.

${ }^{77}$ While Girodet was in Italy Trioson acted as his proxy, surrendering the artist's titles on his behalf. See Girodet's letter from Naples to Trioson, 3 November 1793. Coupin, Oeuvres Posthumes vol II, 442.

78 'Séance du mercredi 20 février 1793, au matin. Lettre de Citoyen Girodet, pensionnaire de la République,' Archives parlementaires de 1789 à 1860: recueil complet des débats législatifs \& politiques des Chambres françaises vol. 74 (Paris: Librairie administrative de P. Dupont, 1862-), 35.

${ }^{79}$ Girodet, Sur la Gloire, in Lemeux-Fraitot, appendix to 'Ut poeta pictor,' 159-177. 
${ }^{80}$ Girodet himself wrote of the Déluge that unfortunate men often pin their hopes 'on rotten branches.' He 'found in this thought the idea of a connection [...] between physical nature and moral nature.' Girodet, 'Aux rédacteurs du Journal,' 1937. This acknowledgment of the painting's allegorical subtext appears to confirm what historians such as Dale Cleaver have argued - that the breaking tree symbolizes 'the fragile structures on which many people depend' in the context of dramatic political transformation. Dale G. Cleaver, 'Girodet's Déluge, A Case Study in Art Criticism,' Art Journal 38 no. 2 (1978-79), 98.

${ }^{81}$ I.G., 'Salon de 1819. Lettre de l'artiste à Pasquin et à Marforio,' La Renommée 157 (1819), 620.

82 Étienne-Jean Delécluze, 'Huitième lettre,' as quoted in Lemeux-Fraitot, 'Ut Poeta Pictor,' 381.

${ }^{83}$ Landon, Salon de 1819, 11, as quoted in Lemeux-Fraitot, 'Ut Poeta Pictor,' 381.

84 'C'est le contact de l'amour qui, comme le feu de l'étincelle électrique, a donné l'ame à la statue!' Auguste-Hilarion de Keratry, Annuaire de l'école française de peinture ou Lettres sur le Salon de 1819 (Paris: Maradan, 1820), 238.

${ }^{85}$ Roy Porter, Flesh in the Age of Reason (New York: Allen Lane, 2003), 215.

86 'Peintre charmant d'Endymion,/Viens jouir des transports de la foule enchantée;/Tout Paris pour ta Galatée,/A les yeux d'Endymion.' Gaucheraud, 'Girodet,' in Biographie universelle, ancienne et modern ou histoire vol. 65 (Paris: L.-G. Michaud, 1838), 415.

${ }^{87}$ This state was closely associated with urban modernity by Walter Benjamin in the 1930s. Although one can find references to this in his seminal 1936 'Art in the Age of Technological Reproducibility,' his discussion of shock is more fully and decisively explored in his 1939 'On Some Motifs in Baudelaire.' Reading Sigmund Freud, Benjamin describes consciousness 
as a defensive barrier against the shocks of modernity. The formal and technical fragmentations of the filmic medium offer a rare means of penetrating this barrier. 